\title{
Effect of storage temperatures on the survival and growth of pathogens in semi preserved foods
}

\author{
Kwaw, Emmanuel \\ Department of Hotel, Catering \& Institutional Management, Cape Coast Polytechnic, Cape Coast, Ghana
}

Email address:

nyangoahkwaw@yahoo.co.uk

\section{To cite this article:}

Kwaw, Emmanuel. Effect of Storage Temperatures on the Survival and Growth of Pathogens in Semi Preserved Foods. International Journal of Nutrition and Food Sciences. Vol. 3, No. 3, 2014, pp. 133-140. doi: 10.11648/j.jpnfs.20140303.11

\begin{abstract}
The effect of storage temperatures on the survival and growth of pathogens in semi preserved foods was assessed using freshly prepared corn dough, dawadawa and cassava dough. Three pathogens, E. coli O157:H7 (Verocytoxigen-negative variant), Yersinia enterocolitica and Salmonella spp. were used. Pathogens were inoculated into $10 \mathrm{~g}$ of samples in sterilized stomacher bags and stored at temperatures of 4,15 and $30^{\circ} \mathrm{C}$. Inoculated samples were sampled at regular time intervals and cultured on selective media. Predictive model was also used to assess how the pathogens will grow in the samples. The water activity $\left(\mathrm{a}_{\mathrm{w}}\right)$ and $\mathrm{pH}$ changes during the storage period were also measured. With the low $\mathrm{a}_{\mathrm{w}}$ of dawadawa (0.87), none of the pathogens could grow in it but growth was possible in corn and cassava dough. The survival and growth of the pathogens were affected not only by the water activity but $\mathrm{pH}$, storage temperatures and time. However it is worth knowing that other physical and chemical properties of the samples which were not considered in the study might have also contributed to the extent to which the pathogens survived and grew in the samples. On the whole, the extent to which the pathogens did survived and grew in the sample depended on the water activity, $\mathrm{pH}$ of the sample and their sensitivity to temperature.
\end{abstract}

Keywords: Dawadawa, Corn Dough, Cassava Dough, Storage Temperature, Storage Time, Growth,

Survival, E. coli O157:H7, Yersinia Enterocolitica, Salmonella Spp, Predictive Model, Growth, Survival

\section{Introduction}

Semi preserved foods are products that keep well for a number of weeks at $2-5{ }^{\circ} \mathrm{C}$, but spoil or become a health risk at ambient temperature within few days [1]. They are mostly preserved by partial modification of their composition, without sterilization but preservation is effected using acids or chemical preservatives, e.g. caviar, fish marinades, dawadawa, corn dough, cassava dough, smoked fish etc. Although these belong to the least stable variety of processed foods, they keep well for one to four weeks when properly refrigerated. Undesirable changes in colour, flavour, odour or texture of the food is used to determine whether the food material is spoilt or not and the rate at which these undesirable changes do occur varies depending on the storage temperature, kind of food, kind of microorganisms present, packaging materials used, food additives used and method of preservation.

Preservation of foods aims at extending the storage life of foods by retarding or preventing changes in flavour, odour, nutritive value, texture or appearance which might result from the activity of undesirable microorganisms. The composition of the general micro flora mostly would determine the extent to which the food will stay on the shelf.

Food has properties that provide an environment favourable or unfavourable for the growth of specific microorganisms. Life in the environment requires the ability to withstand long-periods when growth is not possible. Microorganisms differ greatly in their ability to adapt to different habitats. The extent to which enteric pathogens survive depends on their sensitivity to these factors that enhance growth. However, some biological factor which may be related to changes in genotypes have led to the enhanced survival, resistance or virulence of some microbes to different conditions [2]. For instance, microorganism must expend extra effort to grow in a habitat with low water activity because it must maintain a high internal solute concentration to retain water [3]. Salmonella, Campylobacter, E. coli and Vibrio species can exist in a state where they are viable but cannot be cultured by normal microbiological methods [2]. Under some severe 
conditions such as low nutrient concentration or low temperature, some microbial cells become energy-limited and down-regulate genes except those essential for maintaining cell integrity while others may physically reduce in cell size.

Most foods become potentially hazardous to the consumer only when the principle of sanitation and hygiene are violated. If food is subjected to conditions that allow entry and growth of infectious and toxigenic agents, it becomes the vehicle for transmission of disease. With the increase in number of new emerging, re-emerging or evolving of pathogenic and spoilage microorganisms that have been associated with foodborne illness, the study seeks to assess the effect of storage temperatures on the survival and growth of pathogens in semi preserved foods against the background of indigenous microorganisms.

\subsection{Dawadawa}

Dawadawa is the Hausa name for fermented African locust bean (Parkia biglobosa). Even though there is no written record of its origin [4], the African locust bean is found around villages in the Savannah areas of West Africa. The seed of the plant is mostly used as seasoning even though according to [5], it has other food and non-food uses. The seeds when dehulled and fermented as shown in Figure 1.0 forms a strong smelling food condiment which is called Dawadawa in Niger, Ghana and Northern Nigeria, "Iru" in Southern Nigeria and "Soumbala" in Mali, Ivory
Coast, Burkina Faso and Guinea. It is commonly utilized in West Africa for flavouring soups and stews [6, 7]. Dawadawa has high protein content, essential fatty acids and B-group vitamins and it is a good source of lysine, which is limited in cereal foods [8]. The proximate nutritional composition and the physical changes during fermentation of Parkia seeds are shown in Table 1.0 and 2.0 respectively.

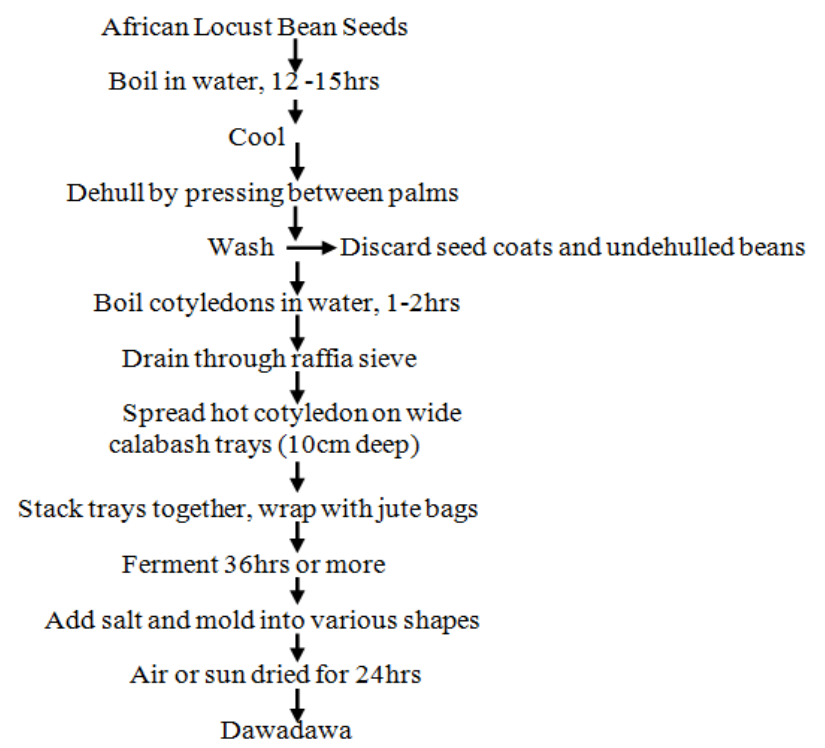

Fig 1.0. Traditional production of Dawadawa.

Table 1.0. Proximate composition and $\mathrm{pH}$ value of Raw and Fermented African locust bean (Parkia biglobosa).

\begin{tabular}{|c|c|c|c|c|c|c|c|}
\hline & Moisture(\%) & $\operatorname{Ash}(\%)$ & $\begin{array}{c}\text { Crude fiber } \\
(\%)\end{array}$ & $\begin{array}{c}\text { Ether } \\
\text { Extract(\%) }\end{array}$ & Crude protein(\%) & CHO(\%) & $\mathbf{p H}$ \\
\hline Raw & $8.6 \pm 0.6$ & $5.4 \pm 0.3$ & $11.7 \pm 0.2$ & $17.7 \pm 0.2$ & $31.0 \pm 0.7$ & $35.0 \pm 0.5$ & 6.2 \\
\hline $\begin{array}{l}\text { Boiled } 12 \mathrm{hr} \& \\
\quad \text { dehulled }\end{array}$ & $51.9 \pm 0.7$ & $3.2 \pm 0.3$ & $4.6 \pm 0.1$ & $20.9 \pm 0.3$ & $31.4 \pm 0.2$ & $42.0 \pm 0.4$ & 6.3 \\
\hline $\begin{array}{l}\text { Boiled 6h } \\
\text { Fermented } \\
\text { period (hrs) }\end{array}$ & $56.7 \pm 0.7$ & $2.8 \pm 0.1$ & $4.4 \pm 0.9$ & $28.4 \pm 0.1$ & $31.1 \pm 0.9$ & $33.3 \pm 0.5$ & 6.4 \\
\hline 24 & $55.7 \pm 0.8$ & $3.6 \pm 0.1$ & $5.7 \pm 0.1$ & $32.6 \pm 0.7$ & $31.7 \pm 0.4$ & $25.0 \pm 1.1$ & 8.3 \\
\hline 48 & $55.5 \pm 0.4$ & $3.5 \pm 0.1$ & $5.4 \pm 0.1$ & $35.2 \pm 0.1$ & $31.3 \pm 0.2$ & $21.0 \pm 0.4$ & 8.4 \\
\hline 72 & $52.0 \pm 5.0$ & $3.6 \pm 0.1$ & $4.0 \pm 0.1$ & $37.2 \pm 0.2$ & $32.9 \pm 0.1$ & $16.3 \pm 0.8$ & 8.4 \\
\hline
\end{tabular}

Source: [9]

Table 2.0. Physical changes during fermentation of Parkia seeds.

\begin{tabular}{cccc}
\hline $\begin{array}{c}\text { Fermenting Time } \\
\text { (hrs) }\end{array}$ & (\%) Moisture content & Temp. ${ }^{\mathbf{o}} \mathbf{C}$ & pH \\
\hline 0 & 43.0 & 25 & 7.0 \\
12 & 48.0 & 30 & 7.2 \\
24 & 54.0 & 42 & 7.5 \\
36 & 56.0 & 45 & 8.1 \\
\hline
\end{tabular}

Adapted from [4]

\subsection{Corn Dough}

Corn (Zea mays) is the predominant cereal crop in West Africa. Corn is used for three main purposes: as a staple human food particularly in the tropics; as feed for livestock particularly in temperate and advanced countries providing over two-thirds of the total trade in feed grains and as a raw material for many industrial products such as flour and cornflakes [10]. Corn is a good source of energy and other essential nutrients.

Corn dough is fermented maize which is an intermediate product used widely in many parts of West Africa to prepare various staple dishes such as kenkey, banku, ogi etc. The unit operations for corn dough preparation and other end uses of the dough are illustrated in Figure 2.0 which indicates the different types of local dishes prepared from fermented dough. The grains are cleaned, washed and steeped in clean water for 24 to 48 hours after which they are milled and mixed with water to form stiff dough which is left to ferment. The fermentation process is spontaneous and uncontrolled [10] 
Studies have been undertaken to identify the microorganisms involved in spontaneous maize fermentation [11]. Molecular biological techniques had also been used to identify and confirmed that Lactobacillus fermentum, Saccharomyces cerevisiae and Candida krusei are the dominant microorganisms in fermented corn dough [12, 13]. Mould genera Penicillium, Aspergillus, Fusarium, and Cephlosporium have been isolated from unfermented maize dough but were not detected after two days of fermentation [11]. Most fermentation involve complex mixtures of microorganisms or a sequence of microbial population changes that result into a desirable product.

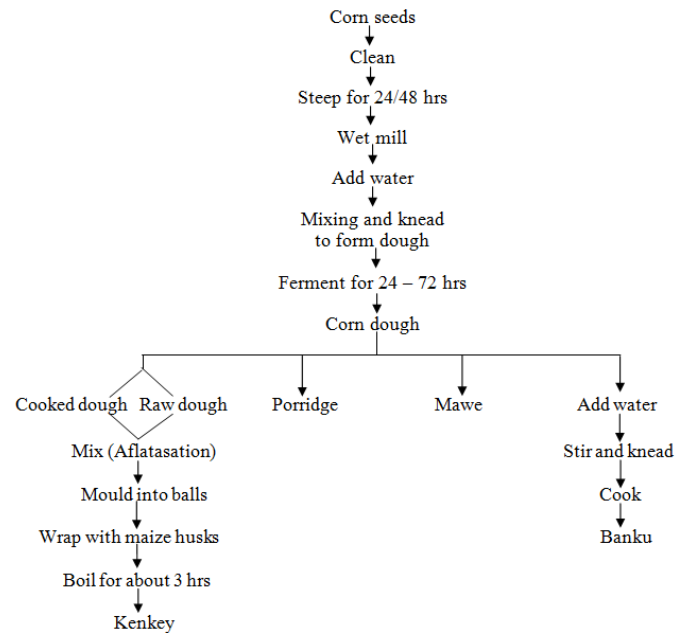

Fig 2.0. Flow Diagram for corn dough production and other end uses.

\subsection{Cassava Dough}

Cassava (Manihot esculenta Crantz) is a root crop and the most abundant starch food in the tropic. There are two varieties of cassava: the sweet and the bitter. The bitter variety contains more cyanogenic glucoside. The roots are fermented to remove considerable amount of cyanide and to modify the texture of the product [14].

Cassava dough is obtained by grating peeled cassava tubers after which the dough is traditionally processed into various fermented products such as gari, candi, kpokpogari, kumkum, myiodo, agbelima etc. The flow diagram for processing some of these products is illustrated in Figure 3.0. These traditionally processed dishes play an important role in the food supply system of Ghana and Sub-Saharan Africa countries [15].

\subsection{Microbial Survival, Growth and Death in Foods}

The survival and growth of microorganisms is a complex process governed by genetic, biochemical and environmental factors [17]. Every food has properties that provide an environment favourable or unfavourable for the growth of specific microorganisms. Microbial growth is an increase in cell numbers resulting in an increase population density. The principles which influence the growth, survival and death of microorganisms in foods are grouped into two. These are the intrinsic (antimicrobial constituents, Water
Activity $\left(\mathrm{a}_{\mathrm{w}}\right)$ and $\mathrm{pH}$ ) and extrinsic factors (temperature, oxygen, light etc.)

\subsection{Possible Cause of Contamination of Cassava Dough, Dawadawa and Corn Dough}

Processing and storage are among the biggest contributors to the microflora of most food products. The degree of contamination of cassava dough, dawadawa and corn dough varies depending on how it is handled from the field to the processing plant till it gets to the final consumer The most likely cause of contamination of these products may be from animal faeces, water, workers, storage containers and processing equipments. Figure 4.0 shows how the raw materials and finished products of cassava dough and corn dough are handled traditionally as well as other possible sources of contaminations.

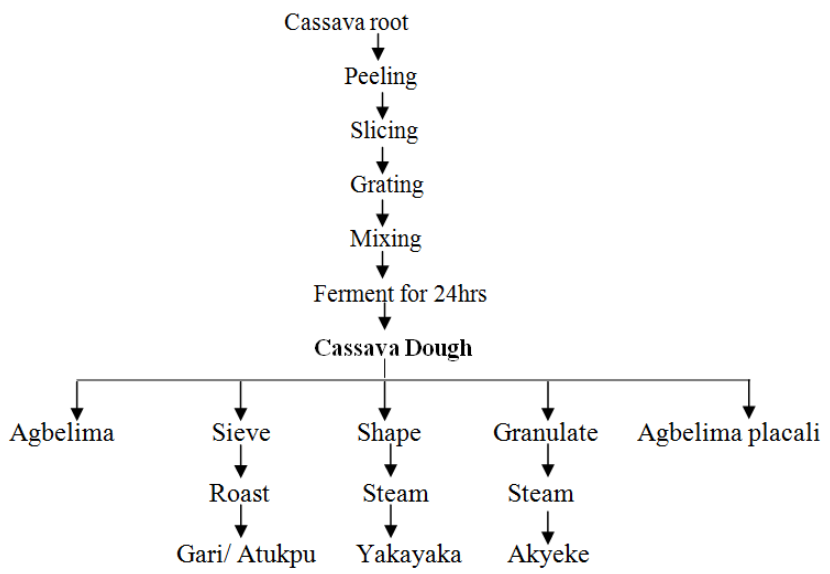

Figure 3.0. Flow diagram for cassava dough production and other end-uses. (Source: [16] but with modifications).

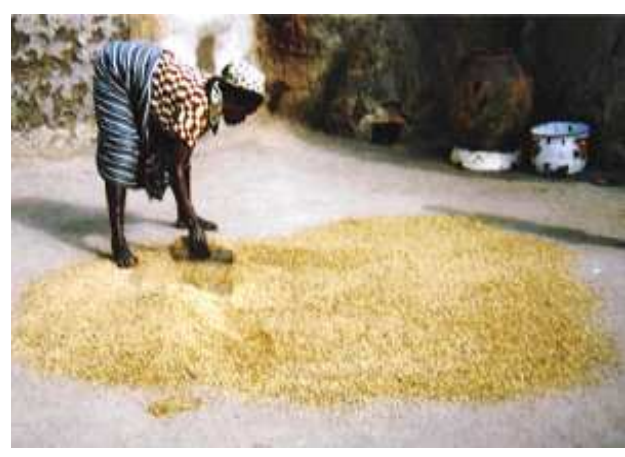

Maize grains been dried on the floor

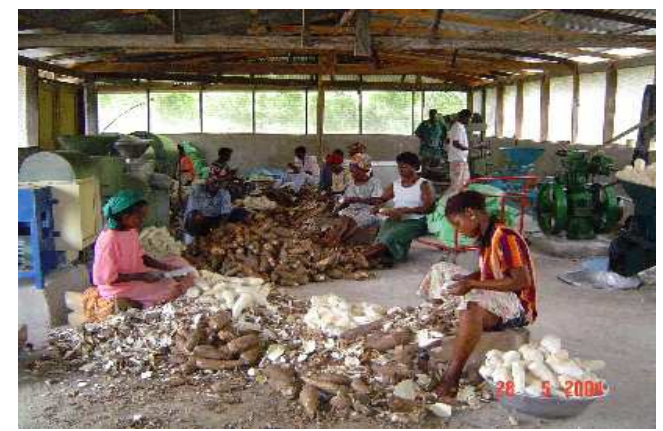

Peeling of cassava tubers for dough preparation 


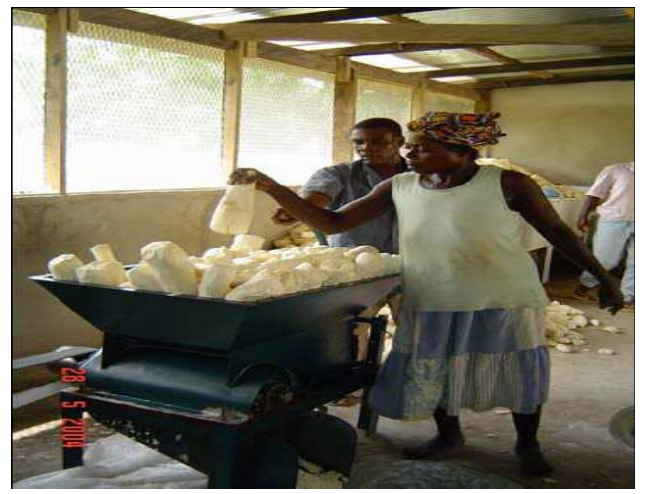

Peeled cassava ready for milling with some left on the floor

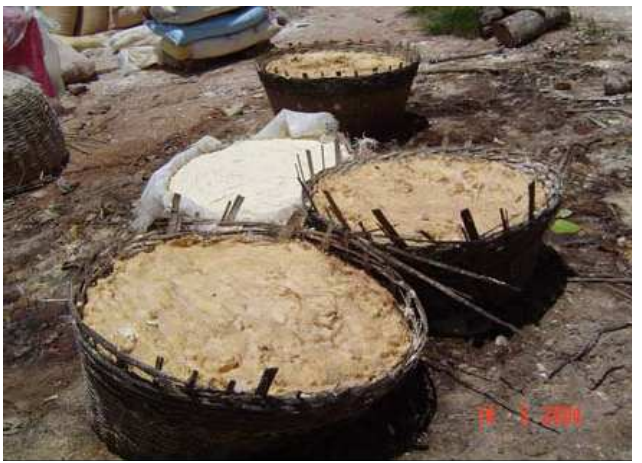

Cassava dough left open to ferment

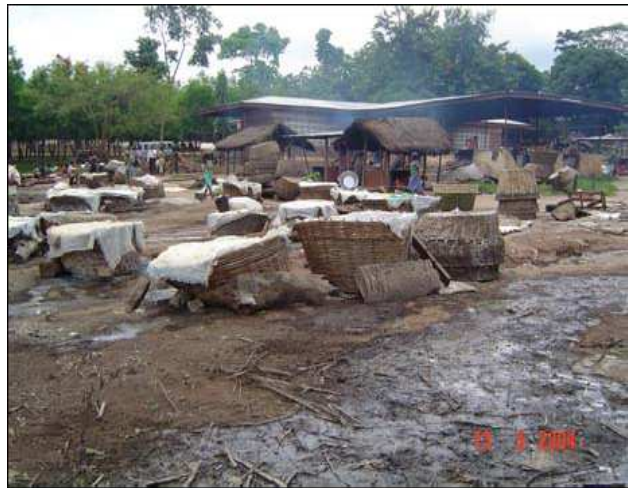

Effluent from fermenting cassava dough trailing on the ground

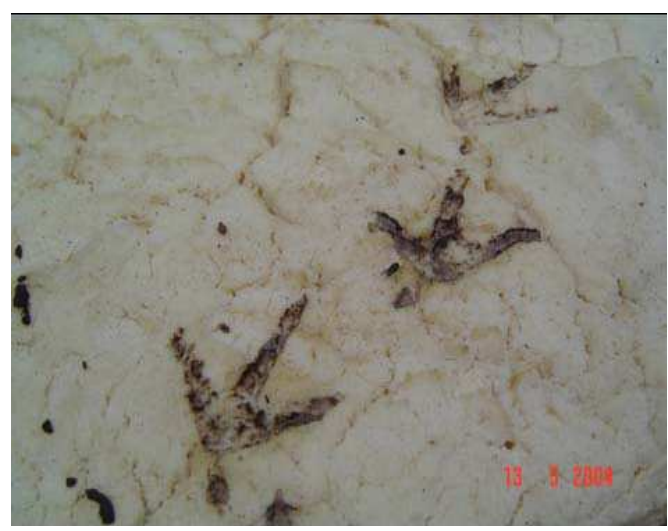

Cassava dough with bird foot prints

Figure 4.0. Possible cause of contamination of Cassava dough, Dawadawa and Corn dough Source of pictures: [18].

\section{Methods}

\subsection{Sample Preparation}

Dawadawa, corn dough and cassava dough were freshly prepared as illustrated in Figure 1, 2 and 3 respectively. Ten grams of the dough were measured into stomacher bags for inoculation.

\section{2. $p H$ and Water activity Determination}

$\mathrm{pH}$ of the refresh prepared samples and that of the stored samples at 4,15 and $30^{\circ} \mathrm{C}$ were measured at regular time interval for each sample as described by [19] while the water activity was then measured using a calibrated AquaLab CX2 water activity meter.

\subsection{Determination of the Growth of Pathogens}

\subsubsection{Inoculation of Samples}

$10.0 \mathrm{~g}$ of each sample were weighed into stomacher bags and inoculated with $100 \mu 1$ of nutrient broth containing about $10^{5} \mathrm{cfu} / \mathrm{ml}$ of the required pathogen to give a final concentration of $10^{3} \mathrm{cfu} / \mathrm{g}$ in the product. The inoculum was massaged into the samples by hand for a minute. Bags containing the inoculated samples were sealed and stored at the appropriate temperatures $\left(4,15\right.$ and $\left.30^{\circ} \mathrm{C}\right)$. A bag each was sampled immediately after inoculation to estimate the initial inoculum concentration. Enumeration of the growth of pathogen was performed as described by [20].

\subsubsection{Verification of Growths of Microorganisms Isolation and Enumeration of Pathogens}

One bag each of the different samples was sampled from the three temperatures at various times during their storage. Dilutions of $10^{-1}$ to $10^{-4}$ were prepared and $20 \mu \mathrm{l}$ of each dilution was spread plated on Hektoen enteric agar, XLD and VRBGA for Salmonella, Yersinia enterocolitica and $E$. coli $\mathrm{O} 157: \mathrm{H} 7$ respectively and incubated at $37^{\circ} \mathrm{C}$ for $24 \mathrm{hrs}$ after which the number of colonies were counted and the colony forming units estimated. This procedure was repeated anytime sampling was done till the growth of the pathogen reached the death phase.

\subsubsection{Predictive Modeling}

Using properties of the samples such as water activity, percentage $\mathrm{NaCl}$ and $\mathrm{pH}$ in combination with the storage temperatures, the predictive growth of each of the pathogens was obtained by substituting values into the Dmodel data base program (J. Baranyi, Institute of Food Research, Norwich, UK). The prediction was repeated for every $\mathrm{pH}$ change during the storage of the sample at temperatures of 4,15 and $30^{\circ} \mathrm{C}$.

\section{Results}

\subsection{Water Activities and Sodium Chloride Content of Samples}

The water activities and the corresponding percentage 
$\mathrm{NaCl}$ of the samples are shown in Table 4.0. Corn dough has a higher water activity than cassava dough and dawadawa with the corresponding percentage $\mathrm{NaCl}$ estimated to be $0.5,1.6$ and 17 respectively.

Table 4.0. Water Activities and Percentage Salts of Samples.

\begin{tabular}{cccc}
\hline Sample & Water Activity & \% NaCl & Temp. $\left({ }^{\mathbf{0}} \mathbf{C}\right)$ \\
\hline Corn dough & 0.997 & 0.5 & 22.6 \\
Cassava dough & 0.991 & 1.6 & 23.0 \\
Dawadawa & 0.870 & 17.0 & 22.6 \\
\hline
\end{tabular}

Table 5.0. $p H$ changes at the different storage temperatures.

\begin{tabular}{|c|c|c|c|c|c|c|c|c|c|}
\hline \multirow{2}{*}{ Duration of Fermentation (Hrs) } & \multicolumn{3}{|c|}{ Corn dough } & \multicolumn{3}{|c|}{ Cassava dough } & \multicolumn{3}{|c|}{ Dawadawa } \\
\hline & $4^{\circ} \mathrm{C}$ & ${ }^{1} 5^{\circ} \mathrm{C}$ & $30^{\circ} \mathrm{C}$ & $4^{\circ} \mathrm{C}$ & $15^{\circ} \mathrm{C}$ & $30^{\circ} \mathrm{C}$ & $4^{\circ} \mathrm{C}$ & $15^{\circ} \mathrm{C}$ & $30^{\circ} \mathrm{C}$ \\
\hline 0 & 6.32 & 6.32 & 6.32 & 6.76 & 6.76 & 6.76 & 6.91 & 6.91 & 6.91 \\
\hline 48 & 5.72 & 5.28 & 4.89 & 6.73 & 5.32 & 5.45 & 7.08 & 7.21 & 7.58 \\
\hline 96 & 5.62 & 4.27 & 4.28 & 4.58 & 5.12 & 4.19 & 7.28 & 7.35 & 7.84 \\
\hline 144 & 5.61 & 4.27 & 3.91 & 4.41 & 4.27 & 3.72 & 7.30 & 7.48 & 8.32 \\
\hline
\end{tabular}

\subsection{Microbial Growth}

\subsubsection{Predictive Growth}

Table 6.0. Predicted growth parameter for the pathogens in corn dough.

\begin{tabular}{|c|c|c|c|c|c|c|c|c|}
\hline No of Conditions & Pathogens & Temp $\left({ }^{\circ} \mathrm{C}\right)$ & $\mathrm{pH}$ & $\% \mathrm{NaCl}$ & incr & lag & dbl.t & sp.gr \\
\hline 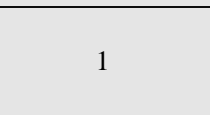 & $\begin{array}{c}\text { E. coli Salmonella } Y \text {. } \\
\text { enterocolitica }\end{array}$ & 22.6 & 6.32 & 0.5 & $\begin{array}{c}12.14 \\
12.89 \\
12.2\end{array}$ & $\begin{array}{c}4.261 \\
4.523 \\
4.28\end{array}$ & $\begin{array}{l}0.8 \\
0.8 \\
0.8\end{array}$ & $\begin{array}{l}0.875 \\
0.825 \\
0.871\end{array}$ \\
\hline 2 & $\begin{array}{c}\text { E. coli Salmonella } Y \text {. } \\
\text { enterocolitica }\end{array}$ & 15.0 & 5.28 & 0.5 & $\begin{array}{l}57.70 \\
72.56 \\
45.98\end{array}$ & $\begin{array}{l}20.24 \\
25.46 \\
16.13\end{array}$ & $\begin{array}{l}3.8 \\
4.7 \\
3.0\end{array}$ & $\begin{array}{l}0.184 \\
0.147 \\
0.231\end{array}$ \\
\hline 3 & $\begin{array}{c}\text { E. coli Salmonella } Y \text {. } \\
\text { enterocolitica }\end{array}$ & 30.0 & 4.89 & 0.5 & $\begin{array}{l}7.547 \\
9.93 \\
22.9\end{array}$ & $\begin{array}{l}2.648 \\
3.484 \\
8.036\end{array}$ & $\begin{array}{l}0.5 \\
0.6 \\
1.5\end{array}$ & $\begin{array}{l}1.408 \\
1.070 \\
0.464\end{array}$ \\
\hline
\end{tabular}

Table 7.0. Predicted Growth parameter for the pathogens in cassava dough.

\begin{tabular}{|c|c|c|c|c|c|c|c|c|}
\hline No of Conditions & Pathogens & $\begin{array}{c}\text { Temp } \\
\left({ }^{\circ} \mathrm{C}\right)\end{array}$ & pH & $\% \mathrm{NaCl}$ & incr & lag & dbl.t & sp.gr \\
\hline \multirow{3}{*}{1} & \multirow{3}{*}{$\begin{array}{c}\text { E. coli Salmonella } Y \text {. } \\
\text { enterocolitica }\end{array}$} & \multirow{3}{*}{23.0} & \multirow{3}{*}{6.76} & \multirow{3}{*}{1.6} & 12.94 & 4.541 & 0.8 & 0.821 \\
\hline & & & & & 12.01 & 4.215 & 0.8 & 0.885 \\
\hline & & & & & 15.30 & 5.367 & 1.0 & 0.695 \\
\hline \multirow{3}{*}{2} & \multirow{3}{*}{$\begin{array}{c}\text { E. coli Salmonella } Y \text {. } \\
\text { enterocolitica }\end{array}$} & \multirow{3}{*}{4.0} & \multirow{3}{*}{5.32} & \multirow{3}{*}{1.6} & 65.35 & 22.930 & 4.3 & 0.163 \\
\hline & & & & & 70.94 & 24.890 & 4.6 & 0.15 \\
\hline & & & & & 58.21 & 20.430 & 3.8 & 0.183 \\
\hline \multirow{3}{*}{3} & \multirow{3}{*}{$\begin{array}{c}\text { E. coli Salmonella } Y \text {. } \\
\text { enterocolitica }\end{array}$} & \multirow{3}{*}{15.0} & \multirow{3}{*}{5.12} & \multirow{3}{*}{1.6} & 75.26 & 26.410 & 4.9 & 0.141 \\
\hline & & & & & 79.28 & 27.820 & 5.2 & 0.134 \\
\hline & & & & & 72.69 & 25.500 & 4.7 & 0.146 \\
\hline \multirow{3}{*}{4} & \multirow{3}{*}{$\begin{array}{c}\text { E. coli Salmonella } Y . \\
\text { enterocolitica }\end{array}$} & \multirow{3}{*}{30.0} & \multirow{3}{*}{5.45} & \multirow{3}{*}{1.6} & 6.39 & 2.194 & 0.4 & 1.646 \\
\hline & & & & & 8.34 & 2.865 & 0.5 & 1.261 \\
\hline & & & & & 16.14 & 5.547 & 1.1 & 0.651 \\
\hline
\end{tabular}

The predicted growths revealed only four possible growth conditions for the pathogens in the corn dough (Table 6) while that of cassava dough were four (Table 7).
The specific growth rate, doubling time, lag time and time for a given amount of the pathogen to increase under the stated conditions are shown in Table 6 and 7.

\subsubsection{Microbial Growth Count}

Table 8. Log microbial counts for the growth of the pathogens in Cassava dough.

\begin{tabular}{|c|c|c|c|c|c|c|c|c|c|}
\hline \multirow{2}{*}{ No of days } & \multicolumn{3}{|c|}{$4^{\circ} \mathrm{C}$} & \multicolumn{3}{|c|}{$15^{\circ} \mathrm{C}$} & \multicolumn{3}{|c|}{$30^{\circ} \mathrm{C}$} \\
\hline & E. coli & Salmonella & Yersinia & E. coli & Salmonella & Yersinia & E. coli & Salmonella & Yersinia \\
\hline 0 & 6.114 & 4.740 & 5.954 & 6.114 & 4.740 & 5.954 & 6.114 & 4.740 & 5.954 \\
\hline 1 & 7.217 & 4.929 & 7.380 & 6.190 & 5.000 & 8.041 & 6.423 & 5.120 & 7.097 \\
\hline 2 & 5.845 & 5.813 & 8.021 & 7.230 & 5.451 & 7.813 & 5.929 & 5.929 & 6.740 \\
\hline
\end{tabular}




\begin{tabular}{cccccccccc}
\hline No of days & E. coli & Salmonella & Yersinia & E. coli & Salmonella & Yersinia & E. coli & $\begin{array}{c}\mathbf{3 0}^{\mathbf{0}} \mathbf{C} \\
\text { Salmonella }\end{array}$ & Yersinia \\
\hline 3 & 3.398 & 6.439 & 5.778 & 4.301 & 6.556 & 4.740 & 5.146 & 6.667 & 5.815 \\
4 & - & 5.813 & 4.176 & - & 5.748 & 4.398 & 4.471 & 5.658 & 4.845 \\
5 & & 5.000 & - & & 5.708 & & & 5.352 & 5.126 \\
6 & & 4.699 & & & 5.380 & & & \\
\hline
\end{tabular}

(-)Missing values: Number of colonies obtained from $10^{-1}$ dilution was less than 10

Table 9. Log microbial counts for the growth of the pathogens in Corn dough.

\begin{tabular}{|c|c|c|c|c|c|c|c|c|c|}
\hline \multirow{2}{*}{ No of days } & \multicolumn{3}{|c|}{$4^{\circ} \mathrm{C}$} & \multicolumn{3}{|c|}{$15^{\circ} \mathrm{C}$} & \multicolumn{3}{|c|}{$30^{\circ} \mathrm{C}$} \\
\hline & E. coli & Salmonella & Yersinia & E. coli & Salmonella & Yersinia & E. coli & Salmonella & Yersinia \\
\hline 0 & 3.176 & 4.875 & 4.322 & 3.176 & 4.875 & 4.322 & 3.176 & 4.875 & 4.322 \\
\hline 1 & 4.538 & 5.398 & 4.462 & 4.544 & 7.423 & 4.699 & 5.623 & 5.591 & 4.568 \\
\hline 2 & 6.217 & 7.903 & 6.243 & 5.371 & 8.371 & 7.097 & 7.230 & 7.00 & 8.531 \\
\hline 3 & 6.371 & 7.813 & 8.415 & 6.556 & 8.332 & 8.447 & 7.217 & 6.176 & 9.130 \\
\hline 4 & 6.061 & 7.477 & 8.740 & 6.146 & 7.778 & 8.903 & 7.079 & 6.000 & 8.978 \\
\hline 5 & 5.000 & 6.146 & 7.398 & 5.929 & 5.544 & 7.362 & 6.021 & 4.301 & 7.813 \\
\hline 6 & 4.929 & 5.114 & 5.813 & 5.602 & 4.322 & 6.954 & 5.813 & 4.000 & 7.061 \\
\hline 7 & 3.398 & 4.471 & 5.079 & 4.471 & 3.398 & 5.778 & 4.301 & 3.301 & 5.699 \\
\hline
\end{tabular}

Table 10. Log microbial counts for the growth of pathogens in Dawadawa.

\begin{tabular}{|c|c|c|c|c|c|c|c|c|c|}
\hline \multirow{2}{*}{ Time(Hrs) } & \multicolumn{3}{|c|}{$4^{\circ} \mathrm{C}$} & \multicolumn{3}{|c|}{$15^{\circ} \mathrm{C}$} & \multicolumn{3}{|c|}{$30^{\circ} \mathrm{C}$} \\
\hline & E. coli & Salmonella & Yersinia & E. coli & Salmonella & Yersinia & E. coli & Salmonella & Yersinia \\
\hline 0 & 5.204 & 5.431 & 5.267 & 5.204 & 5.431 & 5.267 & 5.204 & 5.431 & 5.267 \\
\hline 24 & 2.477 & 2.000 & 2.00 & 2.477 & 2.113 & 2.146 & 2.362 & 2.301 & 2.204 \\
\hline 48 & NG & NG & NG & NG & NG & NG & NG & NG & NG \\
\hline
\end{tabular}

NG - No Growth

The logarithmic growths of the pathogens in the samples are shown in Table 8, 9 and 10. The results depict that growth occurred over 7days in the corn dough, 6days in the cassava dough with some number of colonies obtained from $10^{-1}$ dilution been less than 10 for E. Coli and Yersinia in the cassava dough after 4days. Growths were not detected in dawadawa after 24 hours of incubation.

\section{Discussion and Conclusion}

\subsection{Discussion}

The study revealed that changes in temperature did have an effect on the $\mathrm{pH}$ of the samples. As temperature increased there was corresponding drop in $\mathrm{pH}$ of cassava dough and corn dough (Table 5) since their intrinsic factors were conducive for the growth of the microbes responsible for the acid production during fermentation of the products. However, since the starter culture in dawadawa production is Bacillus subtilis, there was an increase in $\mathrm{pH}$ as temperature increased (Table 5) as a result of alkaline production by the starter culture.

Yersinia enterocolitica is psychrotrophic and known to grow at temperatures between 0 and $44^{\circ} \mathrm{C}$ with optimum growth occurring between $32-34^{\mathrm{O}} \mathrm{C}$ [21]. In the cassava dough, there was an increased in growth of Yersinia enterocolitica between 0 to 3 days at $4^{\circ} \mathrm{C}$ and 0 to 2 days at 15 and $30^{\circ} \mathrm{C}$ after which growth decreased progressively (Table 8). Although it has been reported that, Yersinia enterocolitica can grow in the presence of $5 \% \mathrm{NaCl}$ at 3 and $25^{\circ} \mathrm{C}$ [22], the high water activity of cassava dough
$(0.991, \% \mathrm{NaCl} 1.6)$ caused a decrease in the lag phase of growth hence the increased growth rate during the early stages of fermentation. It was expected that growth rate would be higher at $30^{\circ} \mathrm{C}$ (Table 7). However, with the rapid drop in $\mathrm{pH}$ of the cassava dough at $30^{\circ} \mathrm{C}$ (Table 5), growth was inhibited. The study revealed that $\mathrm{pH}$ changes outweighed the inhibitory effect of lower temperatures on the growth of $Y$. enterocolitica.

In corn dough, optimum growth of Yersinia enterocolitica as shown in Table 9 did occur at $30^{\circ} \mathrm{C}$ after 3days of incubation. Generally, it was observed that conditions for growth of $Y$. Enterocolitica was favourable in corn dough with number of colonies obtained from $10^{-1}$ dilution been more than 10 after 7days of incubation. The predicted growth for Yersinia enterocolitica in corn dough (Table 6) from the combinations of the growth factors also revealed that growth was optimum at $30^{\circ} \mathrm{C}$ with no growth occurring at $4^{\mathrm{O}} \mathrm{C}$. The experimental results cannot be compared to that of the predicted modelling since the model is mathematical and according to [23], it does not take into account dynamic conditions in foods.

In dawadawa, Yersinia enterocolitica did not survive or grow even though the $\mathrm{pH}$ range $(6.91-8.32)$ during the storage period should be favourable for its growth. It has been reported [21], that Yersinia can tolerate 5\% of salt but $7 \%$ prevents its growth. The higher percent salt $(17 \%)$ of dawadawa did not permit the survival or growth of Yersinia enterocolitica.

The range of temperature $\left(7-46^{\circ} \mathrm{C}\right)$ for the growth of Salmonella as reported by [24] indicates that at $4{ }^{\mathrm{O}} \mathrm{C}$ growth would not be possible. The study revealed that at $4^{\mathrm{O}} \mathrm{C}$ 
growth of Salmonella was low. However, factors such as the water activity of the samples as well as other biological factor might have contributed to the survival of the Salmonella at the storage temperature of $4^{\mathrm{O}} \mathrm{C}$. It implies that at $4{ }^{\mathrm{O}} \mathrm{C}$ the microbe expended more effort to survive by adjusting to that condition hence the lower growth rate. The rapid drop in $\mathrm{pH}$ at $30^{\circ} \mathrm{C}$ did also retard the initial grow of Salmonella since the organisms had to adapt to the acidic condition. The lower counts obtained under these conditions might also be due to the fact that the microorganisms might be in a viable state but could not be cultured by the normal microbiological methods used. This characteristic according to [2] can be exhibited by some species of Salmonella, Campylobacter, E. coli and Vibrio. It was observed that growth was optimum at $15^{\circ} \mathrm{C}$ which is an indication that the combined effects of temperature and $\mathrm{pH}$ have significance effect on the growth of Salmonella in corn dough.

In cassava dough, growth did occur over 7days of incubation but there were no significant differences in the log microbial counts among the storage temperatures. However, growth was optimum at $30^{\circ} \mathrm{C}$ on day three. The minimum water activity for the growth of Salmonella is around 0.93 [25] hence the 0.87 water activity of dawadawa did not permit the survival and growth of Salmonella (Table 10).

With the growth of E. coli O157: $\mathrm{H} 7$ in cassava and corn dough, water activity and $\mathrm{pH}$ were not the limiting factors since the minimum water activity and the lowest $\mathrm{pH}$ required for the growth of E. coli is around 0.95 [26] and 3.0 [27] respectively. Some strains of E. coli have been shown to grow at temperatures as low as $4{ }^{\mathrm{O}} \mathrm{C}$ as well as surviving refrigeration or frozen storage for extend time [28, 29]. A study by [28] on the fate of E. coli $\mathrm{O} 157: \mathrm{H} 7$ as affected by $\mathrm{pH}$ or sodium chloride in fermented dried sausage revealed that the microbe did survive at $\mathrm{pH} 4.5$ for up to 2 month at $4{ }^{\mathrm{O}} \mathrm{C}$ with only 100 -fold reduction in cell population. Other studies have reported that low temperatures enhance the survival of $E$. coli $0157: \mathrm{H} 7$ in acid foods [30, 31]. On the other hand, the number of colonies obtained from $10^{-1}$ dilution was less than 10 for $E$. coli at 4 and 15 and $30^{\circ} \mathrm{C}$ after 3 and 4days respectively despite findings from various studies which indicate that the study conditions should have permitted survival and growth of the pathogen. The growth inhibitory factor might be due to factor(s) which were not considered in the study.

\subsection{Conclusion}

Storage of freshly prepared corn dough and cassava dough at temperatures above $4{ }^{\mathrm{O}} \mathrm{C}$ resulted in rapid drop in $\mathrm{pH}$ of the samples while storage of dawadawa at temperatures above $4^{\mathrm{O}} \mathrm{C}$ resulted in increased $\mathrm{pH}$ as a result of the effect of temperature on the activities of the microorganisms responsible for the fermentation of the samples. From the study, storage temperatures have an effect on the growth and/or the survival of E. coli O157:H7, Yersinia enterocolitica and Salmonella in corn dough and cassava dough, with storage at $4^{\mathrm{O}} \mathrm{C}$ generally exhibiting greater inhibitory effect than 15 and $30^{\circ} \mathrm{C}$ in the case where temperature was the limiting factor. In dawadawa, water activity was the main inhibitory factor to the survival and growth of the microorganisms. However, it is worth knowing that other physical and chemical properties of the samples apart from water activity and changes in $\mathrm{pH}$ during the fermentation period which were not considered in the study might have also contributed to the extent to which the pathogens survived and grew in the samples. On the whole, the extent to which the pathogens did survive and grow in the sample depended on the water activity, $\mathrm{pH}$ of the sample and their sensitivity to temperature.

\section{References}

[1] Mossel, D.A.A., Corry, J.E.L., Struijk, C.B. and Baird, R.M. (1995) Essentials of the microbiology of foods. Chichester, UK. John Wiley and Sons Ltd.

[2] Juneja, V. K. and Sofos, J. N. (2002) Control of foodborne microorganisms. New York, USA: Marcel Dekker, Inc.

[3] Prescott, L. M., Harley, J. P., and Klein, D. A. (1993) Microbiology. Second Edition. Dubuque, USA: Wm. C. Brown Publishers.

[4] Odunfa, S.A. and Oyewole, O.B. (1998) African fermented foods. In: Microbiology of Fermented Foods. $2^{\text {nd }}$ Ed. Vol. 2. London, Blackie Academic and Professional.

[5] Audu, I., Oloso, A.O. and Umar, B. (2004) Development of a concentric cyclinder: Locust bean dehuller. J. of Scientific Research and Development. 6, 1-11.

[6] Klanjcar, J., Kopac, M. Kosem, D. and Kozlovic, K. (2002) Dawadawa. URL:http://www.bf.unilj.si/zt/bioteh/seminar _abstract/zivil/ [15/038/2013]

[7] Achi, O.K. (2005) The potential for upgrading traditional fermented foods through biotechnology. African Journal of Biotechnology. 4:5, 375-380.

[8] Diawara, B., Sawadogo, L., Amoa-Awua, W.F. and Jakobsen, M. (2000) Capability building for research and development in quality assurance and fermentation technology for African fermented foods HACCP system for traditional African fermented foods: soumbala. WAITRO.

[9] Omafuvbe, B.O., Falade, O.S., Osuntogun, B.A. and Steve, R.A. (2004) Chemical and biochemical changes in African Locust Bean (Parkia biglobosa) and Melon (Citrullus vulgaris) seeds during fermentation to condiments. Pakistan Journal of Nutrition 3, 140-145

[10] Halm, M., Osei-Yaw, A., Hayford, A., Kpodo, K.A. and Amoa-Awua, W.K.A. (1996) Experiences with the use of a starter culture in the fermentation of maize for 'Kenkey' production in Ghana. World J. of Microbiology and Biotechnology. 12, 1-6.

[11] Jespersen L., Halm, M., Kpodo, K. and Jakobsen, M. (1994) Significance of yeast and moulds occurring in maize dough fermentation for kenkey production. International Journal of Food Microbiology. 24, 239 - 248. 
[12] Hayford, A.E. and Jespersen, L. (1999) Characterization of Saccharomyces cerevisiae strains from spontaneously fermented maize dough by profiles of assimilation, chromosome polymorphism, PCR and MAL genotyping. $J$. Appl. Microbiol. 86, 284-294.

[13] Annan, N.T., Poll, L. and Sefa-Dedah, S. (2003) Influence of starter culture combinations of Lactobacillus fermentum, Saccharomyces cerevisiae and Candida krusei on aroma in Ghanaian maize dough fermentation. Eur. Food Res. Technol. 216, 377-384.

[14] Obilie, E. M., Tano-Debrah, K. and Amoa-Awua, W.K. (2003) Microbial modification of the texture of grated cassava during fermentation into akyeke. International Journal of Food Microbiology. 89, 275-280.

[15] Amoa-Awua, W.K., Frisvad, J.C., Sefa-Dedeh, S. and Jakobsen, M. (1997) The contribution of moulds and yeasts to the fermentation of 'agbelima' cassava dough. Journal of Applied Microbiology. 83, 288-296.

[16] Henry, G., Westby, A. and Collinson, C. (1998) Global cassava end- uses and markets: Current situation and recommendations for further studies. FAO, Rome.

[17] Doyle, M. P., Beuchate, L. R., Montville, T. J. (1997) Food microbiology: Fundamentals and Frontiers. First Edition. Washington DC., USA. ASM Press.

[18] Addy, P.S., Kashaija, I.N., Moyo, M.T, Quynh, N.K., Singh, S. and Walekhwa, P.N. (2004) Constraints and opportunities for small and medium scale processing of cassava in the Asanti and Brong Ahafo Regions of Ghana. Ministry of Food and Agricultural Ghana, Working document series 117.

[19] Food analysis - Quality control in the food and beverage industry. URL:http://food.metrohm com/pdfdownload/Prosp_Lebensmittelanalytik_e_web.pdf $[15 / 02 / 05]$

[20] Roberts, D. and Greenwood, M. (2003) Practical food microbiology. $3^{\text {rd }}$ Edition. Oxford, UK.Blackwell Publishing Ltd.

[21] VanGarde , S.J. and Woodburn, M. (1994) Food preservation and safety: principles and practices. Iowa State University Press, Ames, Iowa.
[22] Sutherland, J.P. and Bayliss, A.J. (1994) Predictive modelling of growth of Yersinia enterocolitica: the effect of temperature, $\mathrm{pH}$ and sodium chloride. International Journal of Food Microbiology. 21, 197 - 215.

[23] Sutherland, J.P. (2003) Modelling food spoilage. In: Food preservation techniques. Ed. Zeuthen, P. and Bogh-Sorensen, L. England, Cambridge: Woodhead Publishing Ltd.

[24] International Commission on Microbiological Specifications for Foods (ICMSF). 1980. Microbial Ecology of Foods. Vol 1. New York, USA: Academic Press.

[25] Adams, M. R., Little, C. L. and Easter, M. C. (1991) Modelling the $\mathrm{pH}$, acidulant and temperature on the growth rate of Yersinia enterocolitica. J. Appl. Bacteriol. 71, 65-75.

[26] Clavero, M.R.S. and Beuchat, L.R. (1996) Survival of E. coli $\mathrm{O} 157: \mathrm{H} 7$ in broth and processed salami as influenced by $\mathrm{pH}$, water activity and temperature and suitability of media for its recovery. Applied and Environ. Microbiol. 62, 2735-2740.

[27] Deng, Y., Ryu, J.H. and Beuchat, L.R. (1999) Tolerance of acid-adapted and acid non-adapted Escherichia coli O157:H7 cells to reduced $\mathrm{pH}$ as affected by type of acidulant. J. Applied Microbiology. 86, 203-210.

[28] Glass, K.A., Loeffelhholz, Ford, J.P. and Doyle, M.P. (1992) Fate of Escherichia coli $\mathrm{O} 157: \mathrm{H} 7$ as affected by $\mathrm{pH}$ or sodium chloride and in fermented, dry sausage. Appl. Environ. Microbiol. 58, 2513-2516.

[29] Han, Y. and Linton, R.H. (2004) Fate of Escherichia coli O157:H7 and Listeria monocytogenes in strawberry juices and acidified media at different $\mathrm{pH}$ values and temperatures. J. Food Proct. 67, 2443-2449.

[30] Zhao, T., Doyle, M.P. and Besser, R.E. (1993) Fate of enterohemorgic E. coli $\mathrm{O} 157: \mathrm{H} 7$ in apple cider with or without preservatives. Applied and Environ. Microbiol. 59, 2526-2530

[31] Conner, D.E. and Kotrola, J.S. (1995) Growth and survival of E. coli O157:H7 under acidic condition. Applied and Environ. Microbiol. 612, 382-385. 